Role of agricultural engineering in environmental and sustainable development for the valley and delta areas: $1953-1982$

\title{
FACTORS INFLUENCING THE QUALITY OF EXTRUDED SINKING AQUATIC FEED PELLETS
}

\author{
Kaddour, $\mathrm{O}^{1,} \quad$ Alavi, $\mathrm{S}^{2} \quad$ and Behnke, $\mathrm{K}^{3}$
}

\section{ABSTRACT}

Aquatic feed production is an important application of extrusion processing. This study focused on the effect of formulation particle size and processing parameters on physical and stability characteristics of extruded sinking shrimp feed. The parameters studied were ration particle size (0.8 and $1.2 \mathrm{~mm})$, single screw extrusion die profile (land length of 2.5 and $5.0 \mathrm{~mm}$; die output area percentage of 4.5 and $6.7 \%$ ), and drying conditions (cooling only and drying followed by cooling). The single screw extruder die $L / D$ ratio was 30: 1, with outlet diameter of 2.5 $\mathrm{mm}$. The same formulation was also pelleted by a ring die pellet mill with die $L / D$ ratio of 13.3: 1 and diameter of $2.38 \mathrm{~mm}$, followed by only cooling of pellets. The quality of feed obtained by extrusion and pellet mill were evaluated. The optimum parameters for sinking feed production by extrusion were - formulation particle size of $0.8 \mathrm{~mm}$, die profile with $5.0 \mathrm{~mm}$ land length and $6.7 \%$ die output area percentage, and drying for $10.5 \mathrm{~min}$ at $210 \mathrm{oC}$ followed by cooling for $5.5 \mathrm{~min}$. The process and pellet quality data for these parameters were $213.2 \mathrm{~kg} / \mathrm{h}$ production rate, $68.4 \mathrm{~kJ} / \mathrm{kg}$ specific mechanical energy (SME), 529.4 $\mathrm{kg} / \mathrm{m} 3$ pellet bulk density, $6.7 \%$ final moisture content, $99.8 \%$ pellet durability, 100\% pellet sinking percentage after immersion for 21-24 h, and water stability of $100 \%$ after $30 \mathrm{~min}, 90 \%$ between $30-60 \mathrm{~min}$ and $80 \%$ between 1-24 $\mathrm{h}$. The corresponding pellet mill results were 444.1 $\mathrm{kg} / \mathrm{h}$ production rate, $23.9 \mathrm{~kJ} / \mathrm{kg}$ SME, $658.3 \mathrm{~kg} / \mathrm{m} 3$ bulk density, $98.4 \%$ durability, $100 \%$ sinking percentage after $45 \mathrm{~min}$, and water stability of $40 \%$ after $15 \mathrm{~min}, 10 \%$ after $30 \mathrm{~min}$ and $0.0 \%$ after $1 \mathrm{~h}$. Results indicated that SME was the most important factor affecting pellet quality, and better quality sinking aquatic feed could be produced using single screw extrusion processing as compared to pellet mill processing.

\footnotetext{
${ }^{1}$ Senior researcher- Agriculture Engineering Research Institute (AEnRI).

${ }^{2}$ Associate professor- Department of Grain Science \& Industry, Kansas State Univ., ${ }^{3}$ Professor- Department of Grain Science \& Industry, Kansas State University Manhattan, KS 66506 Kansas State- USA
} 


\section{PRACTICAL APPLICATION}

The manuscript make focus on the physical and mechanical factors of single screw extruder affecting the sinking aquatic feed pellets quality by studying the die holes profile, formula particle size and drying - cooling profile, the results are very important for extrusion industries to determine the optimum conditions of formula and extruder to produce high quality of pellets, the study used new measurements, it's very important for industries quality control such as the pellets water stability and sinking percentage

\section{INTRODUCTION}

qua feeds increasingly are playing a major role in successful
aquaculture enterprises .Production of variety of commercial
aqua feeds has increased significantly over the past decade and expected to nearly double within the next millennium to more than 15 million TM. Under critical intensive culture conditions, aqua feeds represent as much as $40-60 \%$ of total costs of all aquaculture enterprises. The conversion efficiency of feed into body tissue is generally much higher in fish than farm animals. Fish can convert up to $36 \%$ of feed protein into body protein, whereas beef typically converts only $15 \%$.

The screw extruder was first used as a continuous cooking device in the late-'30s. Today, the extrusion cooker has become the primary continuous cooking apparatus in the commercial production of many snacks, cereals, aquatic feeds, and pet foods. (Brain et al.2001).Extrusion technology is very widely used for the production of floating and non floating aquaculture feeds. . Three feed blends containing $28 \%$ protein with an energy content of $350 \mathrm{Kcal} / 100$ grams were formulated with 20,30 and 40\% of DDGS along with appropriate levels of fish meal, soybean meal, corn flour, vitamin mix and mineral mix. These ingredient blends were extruded in a Brabender single screw extruder at 100, 130, and $160 \mathrm{rpm}$ and 15, 20 and 25\% moisture content and the physical properties were determined. The pellet durability of the extrudates was in the range of 0.37 to 0.96 , and the percentage of DDGS present in the feed significantly affected the pellet durability. The specific ravity of the extrudates which determines the floatability was in the range of 0.82 to 1.05 , and the lowest specific gravity of 0.82 was 
recorded at 20\% DDGS, 20\% moisture and 100 rpm screw speed. Nehru et al (2005)

James et al. (1993) tested the performance of a combination of soybean meal and distiller dried grains as a source of protein, and was compared with fish meal as a source of protein in a prawn culture. Their results indicated that fish meal can be partially or even totally replaced with soybean meal and distillers dried grains in diets for pond production of fresh water prawn in the temperate regions.

Victor et al. (1994) examined two diets containing 32\% protein both with and without fish meal, and a diet containing $36 \%$ protein without fish meal. These were tested in tilapia culture for a period of 103 days. All diets contained ground corn, soy flour, corn distillers grains with solubles, soy oil, fish oil, vitamin mix, and mineral mix. The results showed that the diet containing fish meal with $32 \%$ protein produced no significant increase in weight gain and protein conversion efficiency compared to the $32 \%$ protein diet without fish meal. There was significant increase in weight gain of the tilapia fed with $36 \%$ protein compared to the $32 \%$ protein diet, however.

David (2003) studied the terminology used to describe the characteristics and dimensions of die holes. He reported that the most important terms to understand when selecting a pellet die are: $\mathrm{D}=$ Hole Diameter: Typical hole diameters can range from 3/32nd to 3/4th inch. $\mathrm{L}=$ Effective Length: The effective length is the die thickness that actually performs work on the feed. L/d Ratio: The L/d ratio is the effective length divided by the hole diameter. High $\mathrm{L} / \mathrm{d}$ ratios provide high pellet die resistance as feed moves through the hole and vise versa. Each material has an L/d ratio requirement to form the material into pellets. $\mathrm{T}=$ Total Thickness: Total thickness is the overall thickness of the die. Overall thickness provides the necessary die material to avoid die breakage $\mathrm{X}=$ Counter bore Depth: Counter bore depth measures the "relief" provided in the die as the pellet exits from the die hole.

Nehru et al (2005) extruded ingredient blends containing $28 \%$ protein with distillers dried grains with soluble, soy flour, corn flour, fish meal, mineral mix and vitamin mix was extruded in a C.W. Brabender single screw laboratory extruder using 7 different die nozzles. The die nozzle 
diameter (D), length (L) and L/D ratio of the dies were in the range of 2.0 $\mathrm{mm}$ to $6.0 \mathrm{~mm}, 10.0 \mathrm{~mm}$ to $30.0 \mathrm{~mm}$ and 3.33 to 10.00 , respectively. The moisture content of the ingredient mix was varied from $15 \%$ to $25 \%$ and the temperature of the transition zone and die section were varied from $100^{\circ} \mathrm{C}$ to $140^{\circ} \mathrm{C}$. the results showed that increasing the moisture content of the ingredient mix from $15 \%$ to $25 \%$ had resulted in $2.0 \%, 16.0 \%$, $13.2 \%, 3.2 \%, 63.7 \%$ decrease in bulk density, water solubility index, sinking velocity, mass flow rate and absolute pressure respectively and $11.6 \%, 16.2 \%$ increase in pellet durability and water absorption index respectively. Increasing the cooking temperature had resulted in $17.0 \%$, $5.9 \%, 35.4 \%, 50.6 \%, 28.8 \%, 33.9 \%, 33.9 \%$ decrease in unit density, pellet durability, sinking velocity, absolute pressure, specific mechanical energy, torque and apparent viscosity of the dough respectively, and 23.6 to $49.1 \%$ and $16.9 \%$ increase in dough temperature and water absorption index, respectively.

Single screw extruders have lot of limitations regarding transport of materials inside the barrel and the operation of single screw extruders depends on the pressure requirements of die, slip at the barrel wall and the degree to which the screw is filled. The coupling of these variables along with the type of raw ingredients limits the operation range of single screw extruders (Mercier et al. 1989). The extruder die plays an important role in affecting the process conditions in the extrusion process. The nozzle diameter and length plays important role in affecting the performance of the single screw extruder (Chinnaswamy et al. 1987).

Hill and Pulkinen (1988) reported that pellet durability increased by about 30 to $35 \%$ with an increase in pellet temperature from 60 to $104^{\circ} \mathrm{C}$. A die length-to-diameter ratio (1/d) of 8 to 10 was also reported to be ideal for making high quality pellets. Similarly, Tabil and Sokhansanj (1996) did a study for improving the physical quality of alfalfa pellets by controlling and optimizing the manufacturing process. The process conditions investigated were steam conditioning temperatures, die geometry (length to diameter or 1/d ratio), hammer mill screen sizes used in grinding dry chops and die speed. They reported that higher conditioning temperature $\left(95^{\circ} \mathrm{C}\right)$ resulted in improved durability of 
processed pellets. The durability of samples was generally better using the smaller die (higher $1 / \mathrm{d}$ ratio). The hammer mill screen size did not show any effect on pellet durability. Finally, they reported that high durability pellets are obtained at low die speed (250 rpm).

The maximum pellet quality ( $88 \%$ pellet durability) was achieved with two combinations of steam quality and retention time (70\%-short retention time, $80 \%$-long retention time) for the $14 \%$ moisture mash using the CPM conditioner. A long retention time resulted in the lowest energy consumption $(\mathrm{kWh} / \mathrm{t})$ during pellet production for the $12 \%$ moisture mash with the Bliss conditioner. Feed conditioned to 82.2_C using $100 \%$ quality steam required a lower flow rate $(\mathrm{kg} / \mathrm{h})$ than did the 70\% quality steam for both conditioners. (Gilpin et at 2002).

Larsen et al. (1996) said that the durability was considered high when the percent weight was above $80 \%$, medium for percent weight between 70 to $80 \%$ and low for percent weight below $70 \%$. Three replicates of durability test were performed for each sample.

The extrusion process, characterized by the submission of mixture to high temperature (90-150oC)and the presence of water vapor (pressure of up to $(5 \mathrm{~kg} / \mathrm{cm} 3)$, determines the increase of humidity of mixture, which is up to $26 \%$. These characteristics determine the extruded product density and the desirable physico-chemical aspects of the diet that should be handled in water, which is critical factor of this activity.(Kim et al. 1989).

\section{MATERIALS AND METHODS}

\section{Composition of the sinking aquatic feed formula:}

A fish feed sinking experimental formula was used in the present study, the composition of the formula were wheat flour $20.5 \%$, wheat bran $24 \%$,soy bean $15.5 \%$, fish meal $24 \%$, shrimp meal $10 \%$, premix $2 \%$ and fish oil $5 \%$, the particle size of the formula were $0.8 \mathrm{~mm}$ and $1.2 \mathrm{~mm}$.

\section{Equipment list:}

1-Wenger X-20 single screw extruder system and DDC pre-conditioner system , Sabetha, KS:The specification of the extruder that used to produce sinking aquatic feed pellets were low shear screw profile (single flight -single flight-small steam lock-single flight- small steam lock - 
single flight- medium steam lock - single flight- medium steam lock double flight) .Fig(1A and B). The constant conditions of sinking raw material, pre-condition and extruder were for raw material: moisture $11.1 \%$, bulk density of 524.8 and $519.4 \mathrm{~kg} \mathrm{~cm} 3$ of 0.8 and 1.2 formula particle size , feed temperature of $21 \mathrm{Co}$,feed rate of $195.04 \mathrm{kghh}$ and feed screw speed of 21.85RPM., for pre-conditioner : shaft speed of 400RPM, steam flow $18.21 \mathrm{~kg} \backslash \mathrm{h}$, water flow of $14.91 \mathrm{kghh}$ and discharge temperature of $80.62 \mathrm{C}^{\mathrm{o}}$, for extruder: screw speed $290 \mathrm{RPM}$, steam flow $0.00 \mathrm{~kg} \backslash \mathrm{h}$, water flow of $11.27 \mathrm{~kg} \backslash \mathrm{h}$, head pressure of 200 PSIG and extruder set temperature of 70,80 and $90 \mathrm{C}^{0}$ for zone 1,2 and 3 , respectively.

2--Die holes profile: Back up die No (68347-7) and die holder No (55372-119), different die hole profile designed ,manufactured in winger workshop and were studied of (land length of 2.5 and $5.0 \mathrm{~mm}$; die output area percentage of 4.5 and $6.7 \%$ ), die L/D ratio was 30: 1, with outlet diameter of $2.5 \mathrm{~mm}$.(Fig2 And B).

3--Wenger series 4800 gas -fried dryer (two pass dryer, one pass cooler), Sabetha, KS.

4--Wenger batch mixer 5.5 HP

5--Pneumatic lift system to convey product from extruder to dryer.

6-- Weighing scale (Kubota ), other scale used for bulk density and durability measurements (Ranger Ohaus, Topeka)

7--Dnever instrument IR-200 moisture content measurement unit .

8 -- California pellet mill durability turning box 4 cells. (Fig 3).

9-- Stop watch Casio FX53

10-California pellet mill ring die (CPM):The same formulation was also pelleted by a ring die has L/D ratio of 13.3: 1 and die hole diameter of $2.38 \mathrm{~mm}$. (Fig 4).

Processing Parameters:

Sinking feed formula was extruded by Wenger X-20 single screw extruder system and DDC pre-conditioner system, Sabetha, KS., to study the physical and mechanical factors affecting the shrimp pellets quality . The process parameters were tow different formula particle size of $(0.8 \mathrm{~mm}$ and $1.2 \mathrm{~mm})$ as a physical parameters, Die holes profile of die profile $1(30$ hole $(6.68 \%)+2.5 \mathrm{~mm}$ land length $)$, die profile $2(30$ hole $(6.68 \%)+5 \mathrm{~mm}$ land length $)$, die profile $3(20$ hole $(4.54 \%)$ 
$+2.5 \mathrm{~mm}$ land length and die profile 4 (20 hole $(4.54 \%)+5 \mathrm{~mm}$ land length, and cooling and drying profile of (drying for $10.5 \mathrm{~min}+$ cooling for $5.5 \mathrm{~min}$ ) and just cooling for $5.5 \mathrm{~min}$ as mechanical parameters. This constituted a $2 \times 4 \times 2$ factorial experimental design.

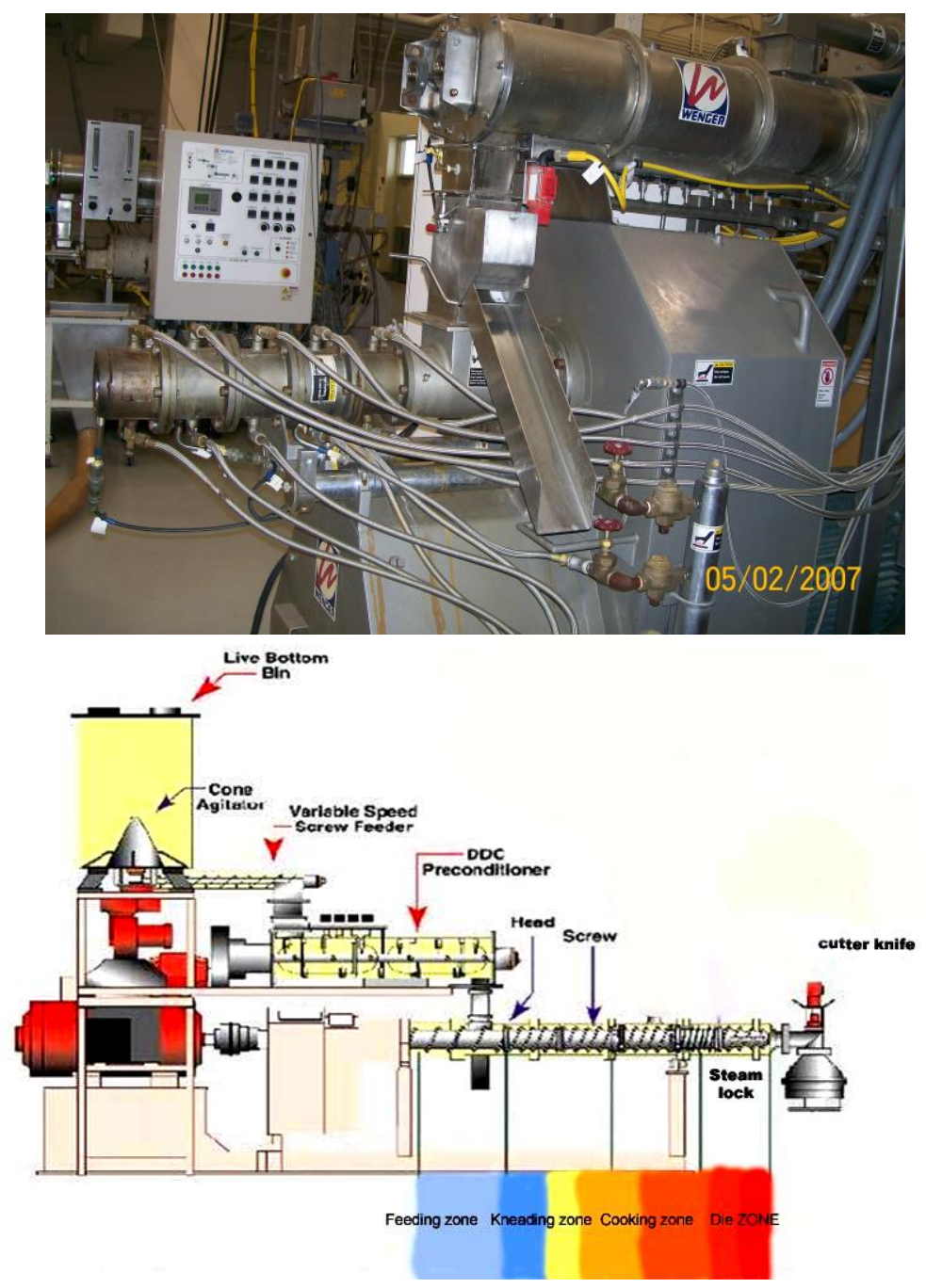

(A)

(B)

Fig.(1A and B) A Picture of Wenger X-20 single screw extruder system and DDC pre-conditioner system , Sabetha, KS, B a Cross section on the single screw extruder 


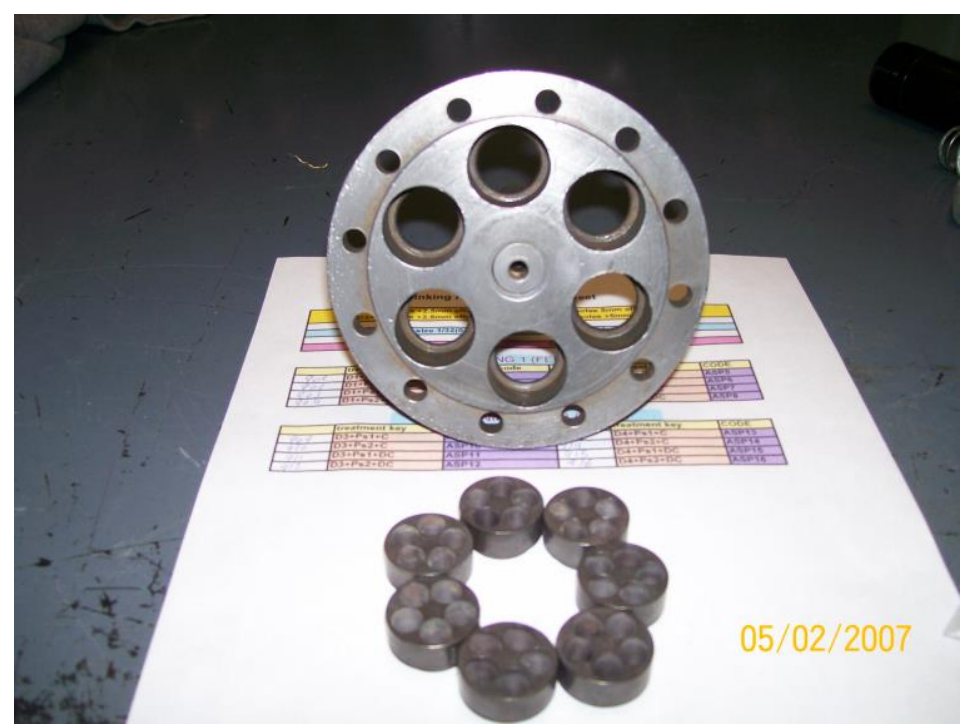

(A)

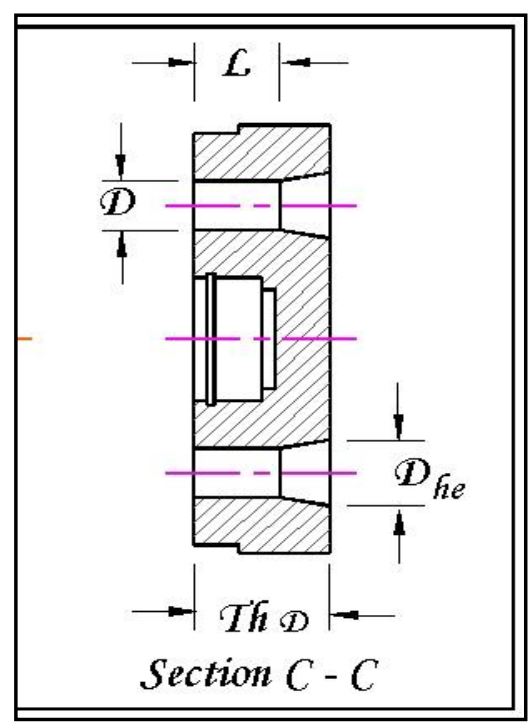

(B)

\begin{tabular}{|c|c|c|c|c|c|}
\hline $\begin{array}{c}\text { N } \\
\text { (holes) }\end{array}$ & $\begin{array}{c}\text { Dhe } \\
(\mathrm{mm})\end{array}$ & $\begin{array}{c}\text { At } \\
\left(\mathrm{mm}^{2}\right)\end{array}$ & $\begin{array}{c}\mathrm{L} \\
(\mathrm{mm})\end{array}$ & $\begin{array}{c}\text { A h } \\
\left(\mathrm{mm}^{2}\right)\end{array}$ & OPEING ARIA \\
\hline $20-30$ & 7.52 & 1980.25 & $\begin{array}{c}5 \text { and } \\
2.5\end{array}$ & 4.41 & $88.2 \mathrm{~mm}^{2}$ and $132.3 \mathrm{~mm}^{2}$ \\
\hline
\end{tabular}

Fig.(2A and 2B)Wenger X-20 single screw extruder Sabetha, KS die profile and die hole dimensions . 


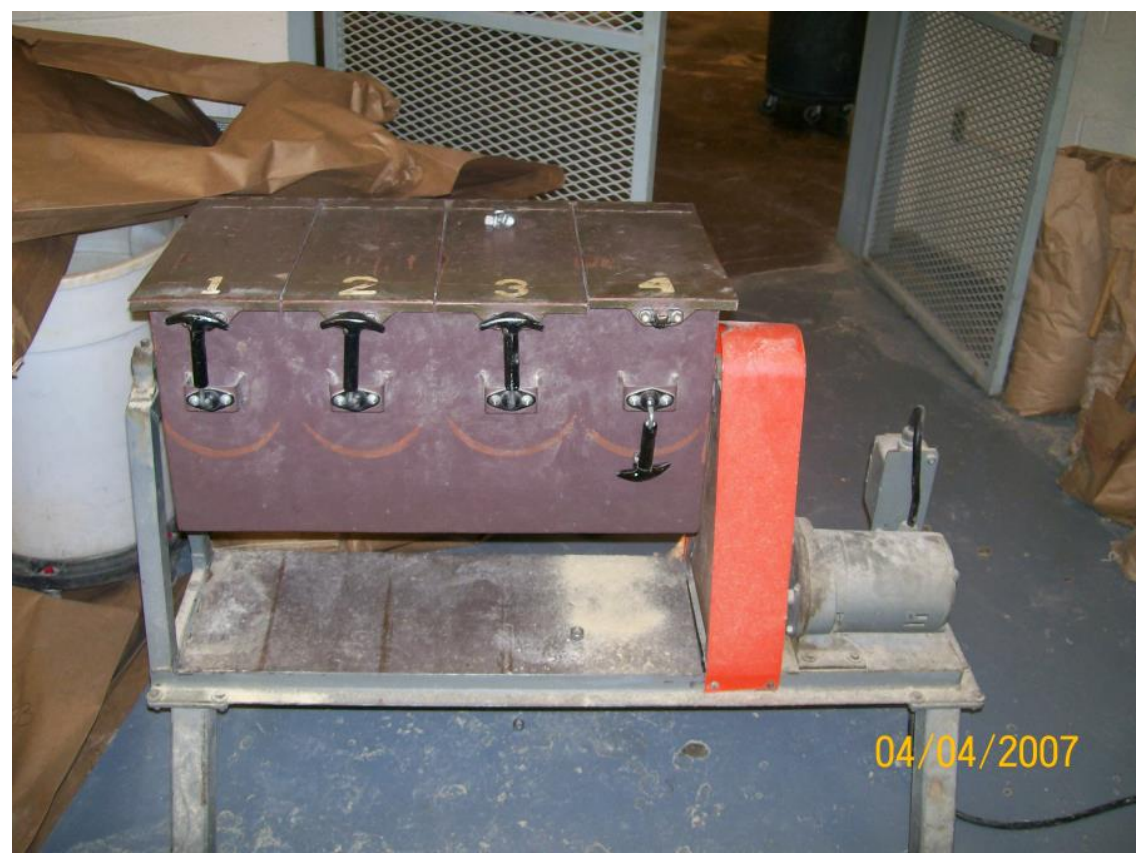

Fig.(3): California pellet mill durability turning box 4 cells

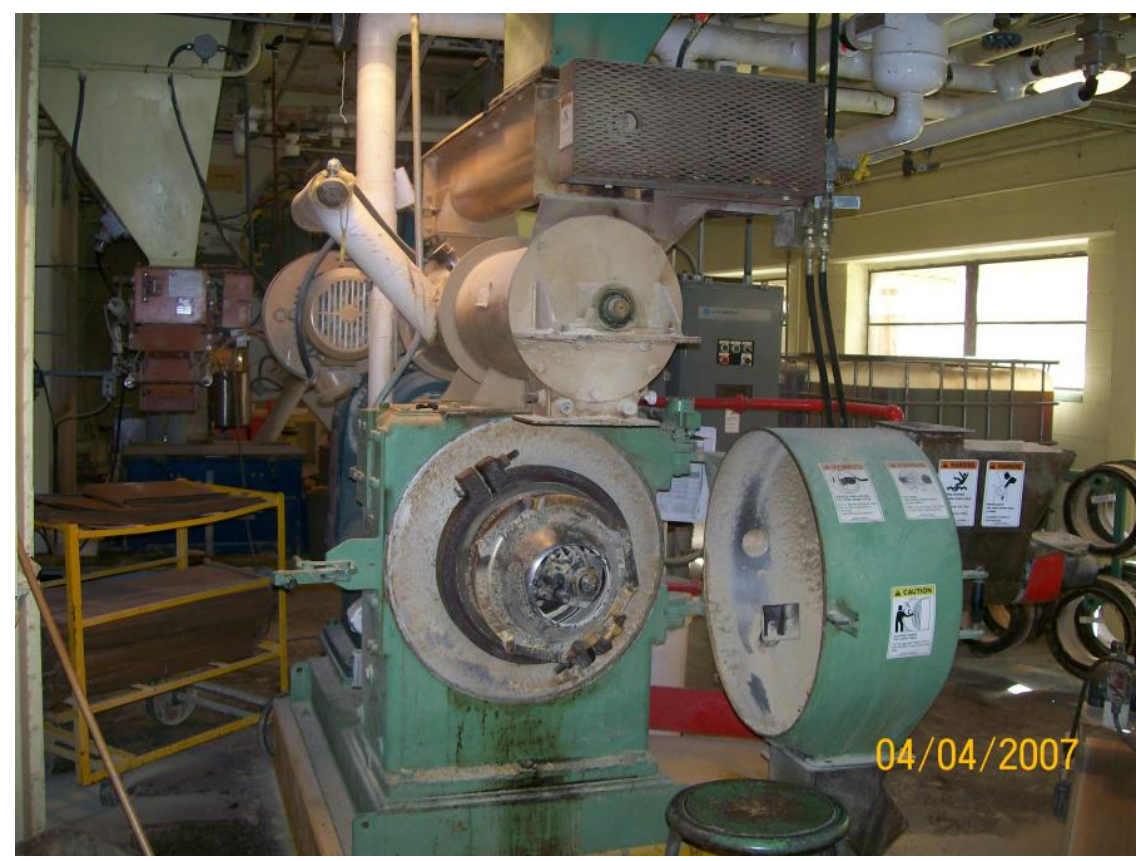

Fig.(4): California pellet mill ring die (CPM) 


\section{Evaluation of sinking pellet quality Performance}

The experimental study running and collecting the sample, data analysis and write the manuscript through April 2007 to September 2008 at extrusion laboratory of grain science and industry department Manhattan Kansas , 66506 .Aquatic feed shrimp pellets were produced by a single screw extruder using dies with $2.5 \mathrm{~mm}$ diameter circular openings. The extruder factors performance was evaluated for extruder efficiency and pellets quality based on the following measurements: 1-Extruder productivity 2- Specific mechanical energy (SME), 3-Pellet bulk density, 4-Final moisture content, 5-Pellet durability,6- pellet expansion ratio 7 - Pellets sinking percentage 8 -Pellets water stability.

1- Extruder production rate was measured for each treatment by taking sample for 2 min after 15 min. of extruder running.

2- Specific mechanical energy (SME), was calculated using the following relation:

$$
\mathrm{SME}=\{(\% \mathrm{~T}-\% \mathrm{~T} 1) * \text { Power kw*(N/N1) }\} / \mathrm{M} \mathrm{kg} / \mathrm{s}
$$

Where: $(\mathrm{SME})=$ specific mechanical energy $\mathrm{T}=$ Motor load $\%$ in load $\mathrm{T} 1=$ Motor load without load \% (0.05) $\mathrm{N}=$ Screw speed rpm , N1: Valid screw speed RPM(500 rpm) and $\mathrm{M}=$ Production rate $\mathrm{kg} / \mathrm{s}$

3- Pellet bulk density was calculated using Standard method of Feed Manufacturing (American Feed Industry Association, Inc., 2005 .

4- Pellet final moisture content was measured $\mathrm{OE}$ after extrusion and OD after Drying and cooling to evaluate the effect of process after extruded (drying and cooling ) on final pellet moisture content .

5- Pellets durability was calculated using Standard method of Feed Manufacturing (American Feed Industry Association, Inc., 2005 , by 4 replicates the mass of etch one was $500 \mathrm{~g}$ using turning box for $10 \mathrm{~min}$.

6- Pellet expansion ratio was calculated by measuring the pellet diameter after extruded using the formula

$$
S E I=\frac{D_{e}^{2}}{D_{d}{ }^{2}}(\text { ratio })
$$

Where De: Extruded pellet diameter

Dd: Die hole diameter 
7- Pellet water stability was calculated by put the pellet in glass water and measure the number of pellet still stable in water after ( start,15, 30,45 min, 1 , 3 , 6,12 and 24 hour) using formula:

Pellet water stability $=$ Ns1 $\backslash$ Nt $\times 100$

Where Ns: Number of stable pellets in the water Nt: Total pellets sample.

8- Pellet sinking percentage was calculated by put the pellets sample in glass tank and measure the number of sinking pellet after ( start, 15, 30,45 min, $1,3,6,12$ and 24 hour) using formula :

Pellet sinking percentage $=$ Ns $\backslash$ Nt $\times 100$

Where Ns: Number of sinking pellets in the water and Nt: Total pellets sample.

\section{RESULTS AND DISCUSSION}

\section{Extruder production rate:}

The effect of die profile and formula particle size on extruder production rate ,data in $\operatorname{Fig}(5)$ showed that no significant effect of die profile on extruder productivity, change die profile from 1 to 2,3 and 4 the production rate decrease from 218.54to 213.8, 209.7 and $206.77 \mathrm{~kg}$ h using formula particle size of $0.8 \mathrm{~mm}$, and from 218.4 to $213.2,209.22$ and $206.37 \mathrm{~kg}$ h using formula particle size of $1.2 \mathrm{~mm}$.the same trend data showed for the effect of formula particle size, no significant effect for particle size on extruder productivity. On another hand using the same formula with ring die pelleting machine data in the same figure showed that increasing the ration particle size from $0.8 \mathrm{~mm}$ to $1.2 \mathrm{~mm}$ decreased the machine productivity from 441.6 to $417.6 \mathrm{~kg} \backslash \mathrm{h}$.

The slight decrease in production rate by change die profile 1 to 2 could be due to the increase in die hole land length from $2.5 \mathrm{~mm}$ to $5 \mathrm{~mm}$, that is deal to in crease the formula retention time in the die hole, while the decrease in production rate by change the die profile 1 to 3 or from 2 to 4 could be due to the decrease in die out put area from $6.68 \%$ (30 holes) to $4.54 \%$ (20holes), that increase the formula retention time in extruder barrel . 


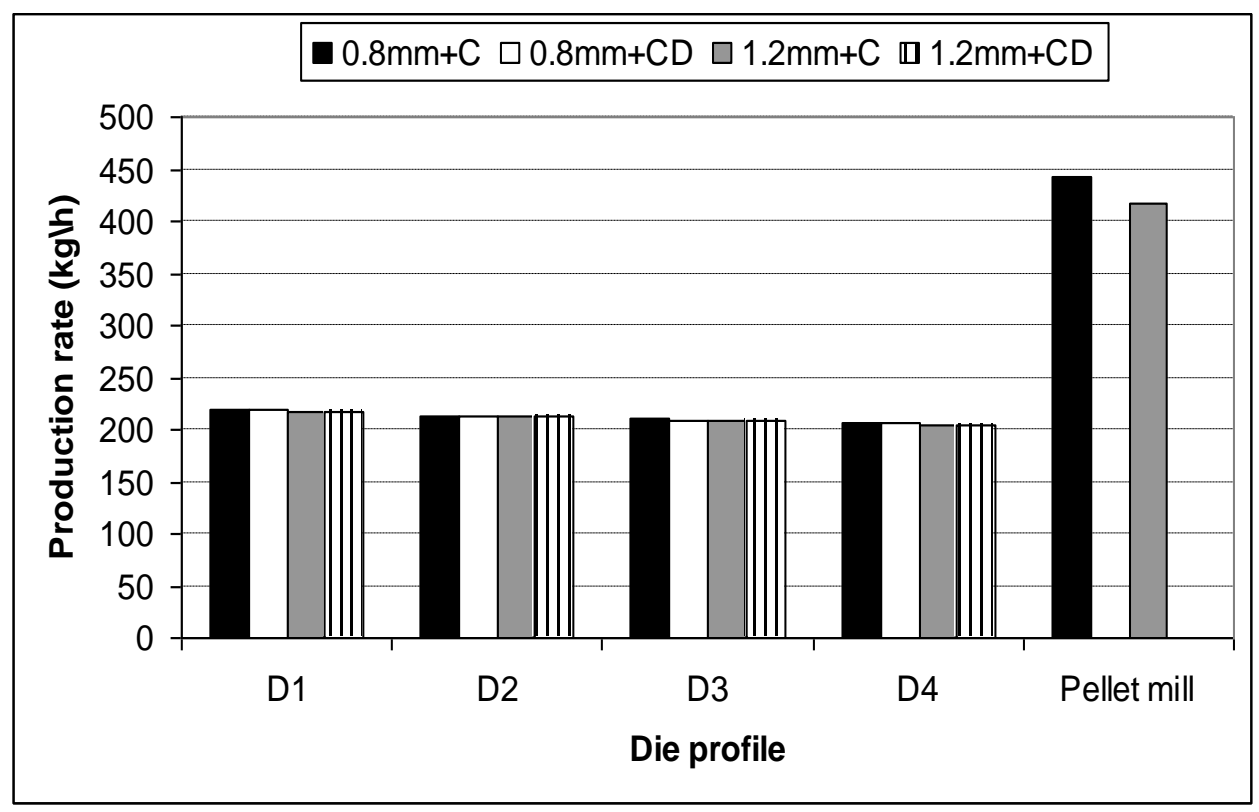

Fig(5) Effect of die holes profile, formula particle size and cooling and drying with cooling on production rate.

\section{Extruder specific mechanical energy (SME) :}

The effect of die profile and formula particle size on extruder specific mechanical energy data in Fig (6) showed that change the die profile from die 1 to die 2, 3 and 4 increase the SME from 63.30 to $68.43,73.54$ and $78.42 \mathrm{~kW}$.hlton using formula particle size of $0.8 \mathrm{~mm}$, and from 63.49 to $68.67,73.90$ and $82.27 \mathrm{~kW}$.hlton. While the effect of ration particle size showed in the same figure indicated that increasing the formula particle size from $0.8 \mathrm{~mm}$ to $1.2 \mathrm{~mm}$ increased the SME slightly from 63.29 to $63.50,68.42$ to $68.67,73.53$ to 73.90 and from 78.42 to $82.27 \mathrm{~kW}$.hlton, using die profile of 1, 2, 3 and 4 respectively.

The increase in SME by changing the die profile from die 1 to die 2 or die 3 to die 4 could be due to the increase in die hole land length, that increase the formula retention time in the die hole, while the increase in SME by changing die 1 to die 3 or die 2 to die 4 could be due to the decease in die out put area (number of holes), that increase the formula retention time inside the extruder barrel that increased the motor load. 


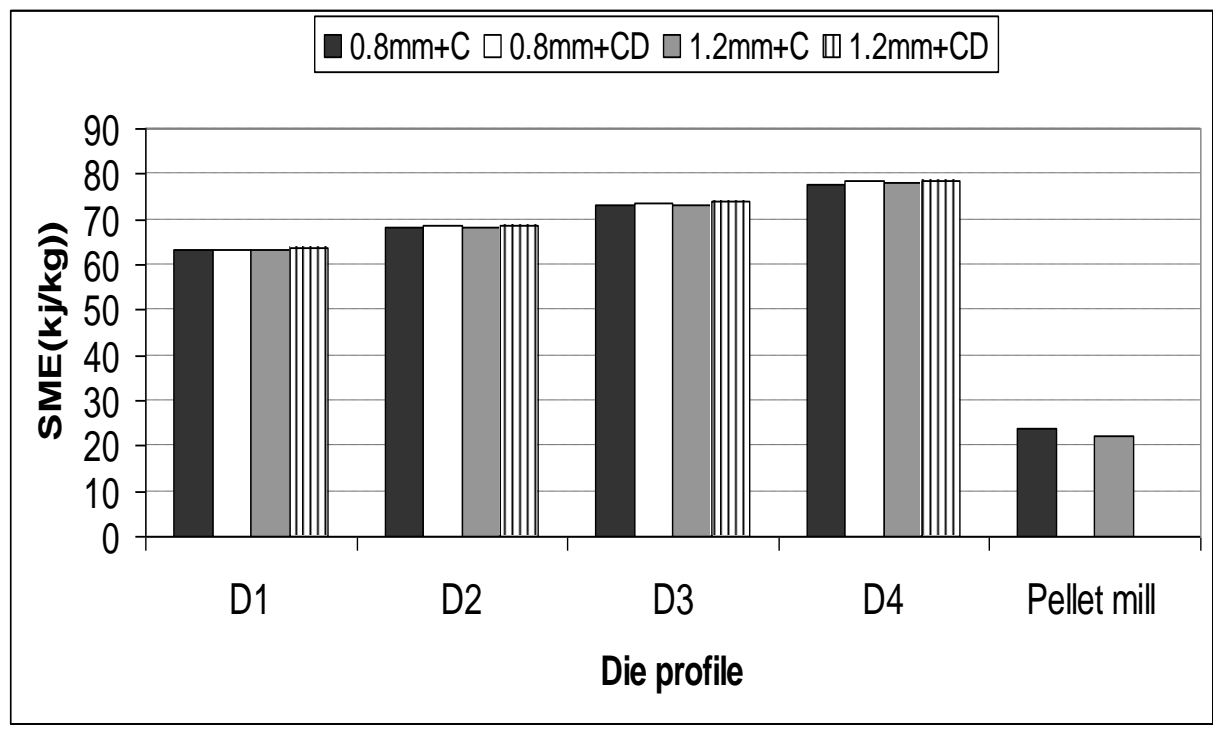

Fig(6) Effect of die holes profile, formula particle size and cooling and drying on specific mechanical energy (SME) .

\section{Pellets output moisture content (OE\&OD):}

The effect of die profile, formula particle size and drying cooling profile on pellets out put moisture content OE (after extruder) and OD (after drying and cooling data in $\operatorname{Fig}(7 \mathrm{~A} \& \mathrm{~B})$ showed that change the die profile from 1, 2, 3and 4 the moisture content decreased from 27.81, $26.29,24.78$ and $25.60 \%$ after extruder (OE) to 19.24, 20.92, 19.63 and $19.80 \%$ after cooling (OD) and from 27.33, 26.29, 25.73 and $25.62 \%$ after extruder (OE) to 6.88,6.66,4.96 and 5.00\% after drying and cooling (OD) using formula particle size of $0.8 \mathrm{~mm}$ while it decreased from $27.28,26.85,23.91$ and $27.09 \%$ after extruder(OE) to $18.9,21.52,19.17$ and $21.22 \%$ after cooling (OD) and from 26.28, 24.87, 25.15 and 26.02\% after extruder (OE) to 5.64,6.36,5.04 and 4.24\% after drying and cooling (OD) using formula particle size of $1.2 \mathrm{~mm}$.

From the data it is clear to see no trend effect for die profile on pellets out put moisture content, while increasing the formula particle size from $0.8 \mathrm{~mm}$ to $1.2 \mathrm{~mm}$ decreased the pellets moisture out put using drying and cooling profile, that could be due to the easy removing of moisture in the air cells between the formula granules .On another hand using just 
cooling profile can not decrease the pellets out put moisture content to the optimum moisture for storage (less than $8 \%$ ).
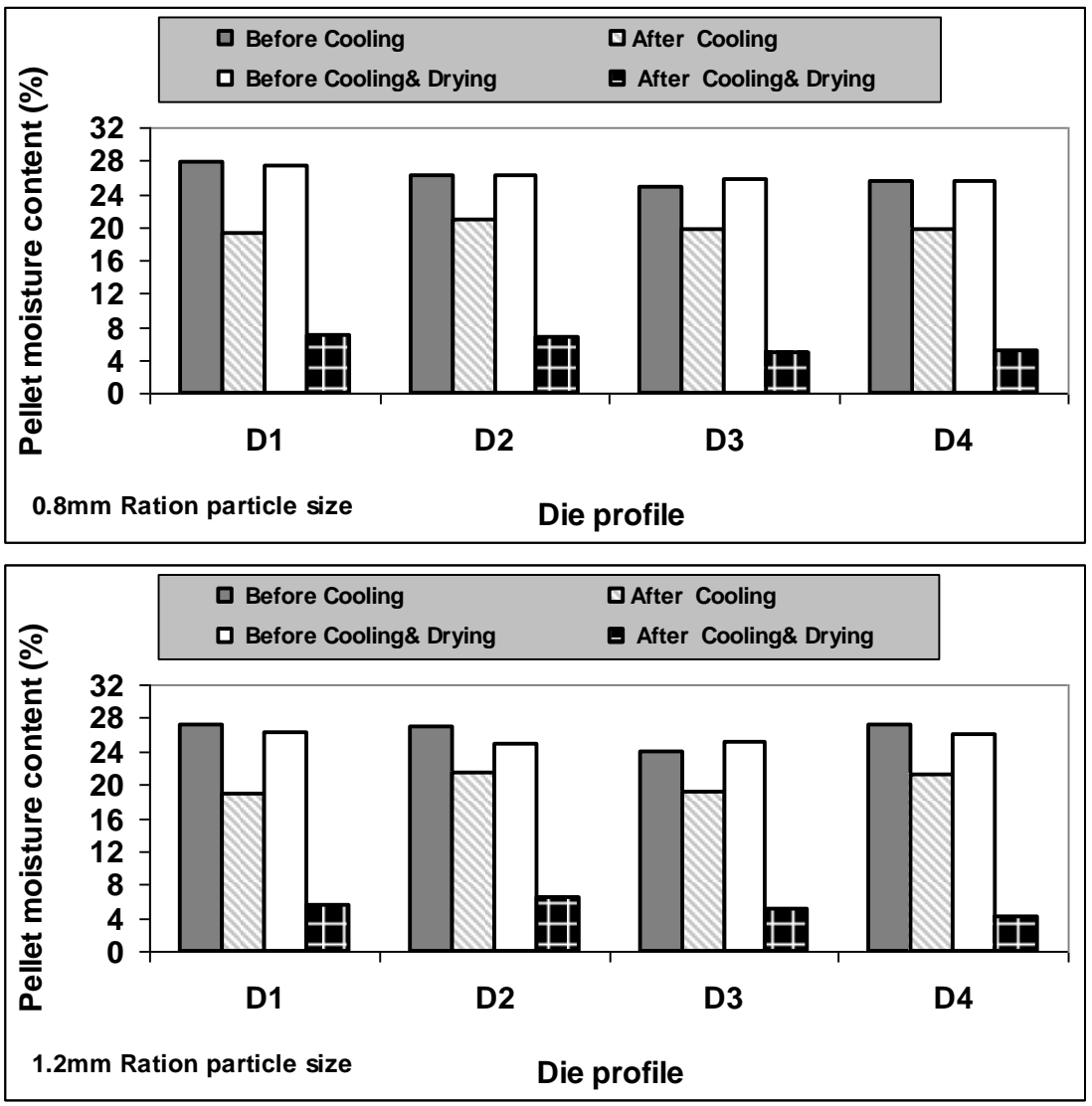

Fig(7A\&B) Effect of die holes profile and cooling and drying on pellet moisture content.

\section{Pellets bulk density :}

Data in $\operatorname{Fig}(8 \mathrm{~A} \& \mathrm{~B})$ showed the effect of die profile, formula particle size and drying and cooling profile on pellets bulk density .Changing the die profile from die 1 to die 2 and from die 3 to die 4 increased the pellets bulk density from 510 to $529.4 \mathrm{~kg} \backslash \mathrm{m} 3$ and from 482 to $517 \mathrm{~kg} \backslash \mathrm{cm} 3$ using formula particle size of $0.8 \mathrm{~mm}$,from 507.2 to 518.8 and 478.5 to 515 $\mathrm{kglcm} 3$ using formula particle size of $1.2 \mathrm{~mm}$ with drying and cooling profile, from513 to $532 \mathrm{~kg} \backslash \mathrm{m} 3$ and from 492.1 to $522 \mathrm{~kg} / \mathrm{cm} 3$ using formula particle size of $0.8 \mathrm{~mm}$, from 511 to 521 and 486 to $516 \mathrm{kglcm} 3$ using formula particle size of $1.2 \mathrm{~mm}$ with just cooling profile. 

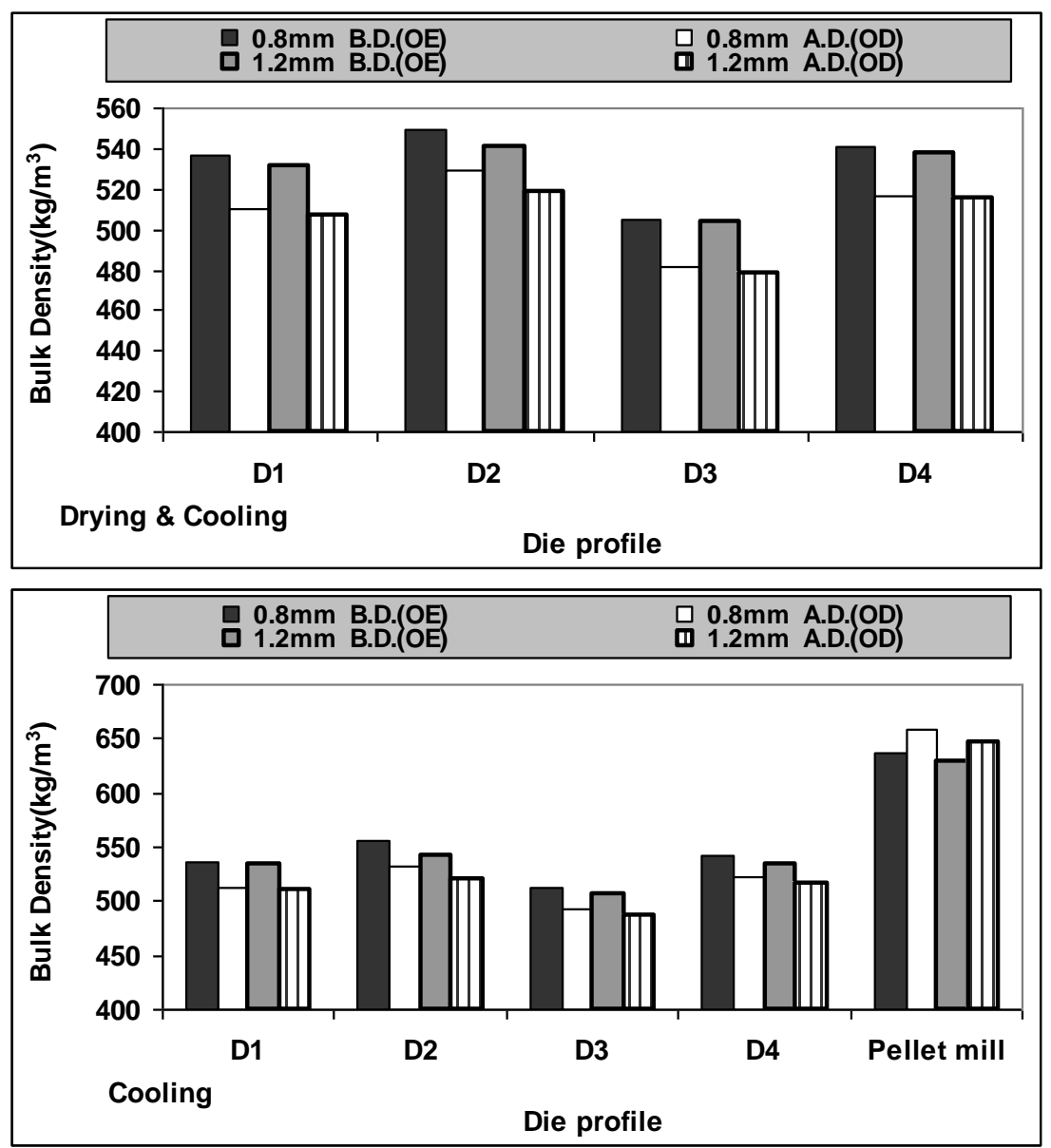

Fig $(8 A \& B)$ Effect o die pofile, formula particle size after extruded OE and after cooling OD on pellet bulk density.

While changing the die profile from die 1 to die 3 and die 2 to die 4 decreased the pellets bulk density from 510 to $482 \mathrm{~kg} \backslash \mathrm{m} 3$ and from 529.4 to $517 \mathrm{~kg} / \mathrm{cm} 3$ using formula particle size of $0.8 \mathrm{~mm}$, from 507.2 to 478.5 and 518.8 to $515 \mathrm{kglcm} 3$ using formula particle size of $1.2 \mathrm{~mm}$ with drying and cooling profile, from513 to $492.1 \mathrm{~kg} \mid \mathrm{m} 3$ and from 532 to 522 $\mathrm{kglcm} 3$ using formula particle size of $0.8 \mathrm{~mm}$, from 511 to 486 and 521 to $516 \mathrm{~kg} / \mathrm{cm} 3$ using formula particle size of $1.2 \mathrm{~mm}$ with just cooling profile . Data in Fig $(8 \mathrm{~B})$ showed the effect of using ring die pelleting machine with the same formula particle sizes, it indicated that using ring 
die pelleting machine increased the pellets bulk density to 658.3 and $646.8 \mathrm{~kg} \mathrm{lcm} 3$ using formula particle size of 0.8 and $1.2 \mathrm{~mm}$ respectively.

The increase of pellets bulk density by changing the die profile from 1to 2 or 3 to 4 could be due to the increase in die hole land length that increasing the formula holding time in the die hole, while the decreased in pellets bulk density by changing die profile from die 1 to 3 or 2 to 4 could be due to the decrease in die out put area (number of holes ) and that increased the SME inside the extruder barrel that cause to increase the pellets out put diameter. On another hand the high increase in pellets bulk density by using ring die pelleting machine could be due to the decrease in SME in this kind of pelleting machine.

Regarding to the decrease in pellets bulk density by increased the formula particle size from 0.8 to $1.2 \mathrm{~mm}$ could be due to the decrease in pellets mass by increasing the air cells between the formula granules. About the increase in pellets bulk density by using cooling profile than using drying and cooling profile could be due to the increase in pellets mass by the increase in moisture holed between the pellet granules.

\section{Pellets durability :}

The effect of die profile, formula particle size and drying and cooling profile is shown in Fig (9) .Data indicated that changed the die profile from die 1 to die 2 increased the pellets durability from 97.7 and 98.6 to 99.4 and $99.8 \%$ using formula particle size of $0.8 \mathrm{~mm}$, and from 97 and 99.3 to 99.2 and $99.4 \%$ using formula particle size of $1.2 \mathrm{~mm}$ with just cooling and drying and cooling profile respectively, while changed the die profile from die 1 to die 3 increased the pellets durability from 97.7 and 98.6 to 99 and $99.3 \%$ using formula particle size of $0.8 \mathrm{~mm}$, and from 97and 99.3 to 98 and $99.8 \%$ using formula particle size of $1.2 \mathrm{~mm}$ with just cooling and drying and cooling profile respectively. On another hand using ring die pelleting machine decreased the pellets durability to 98.4 and $98 \%$ using formula particle size of 0.8 and $1.2 \mathrm{~mm}$. 


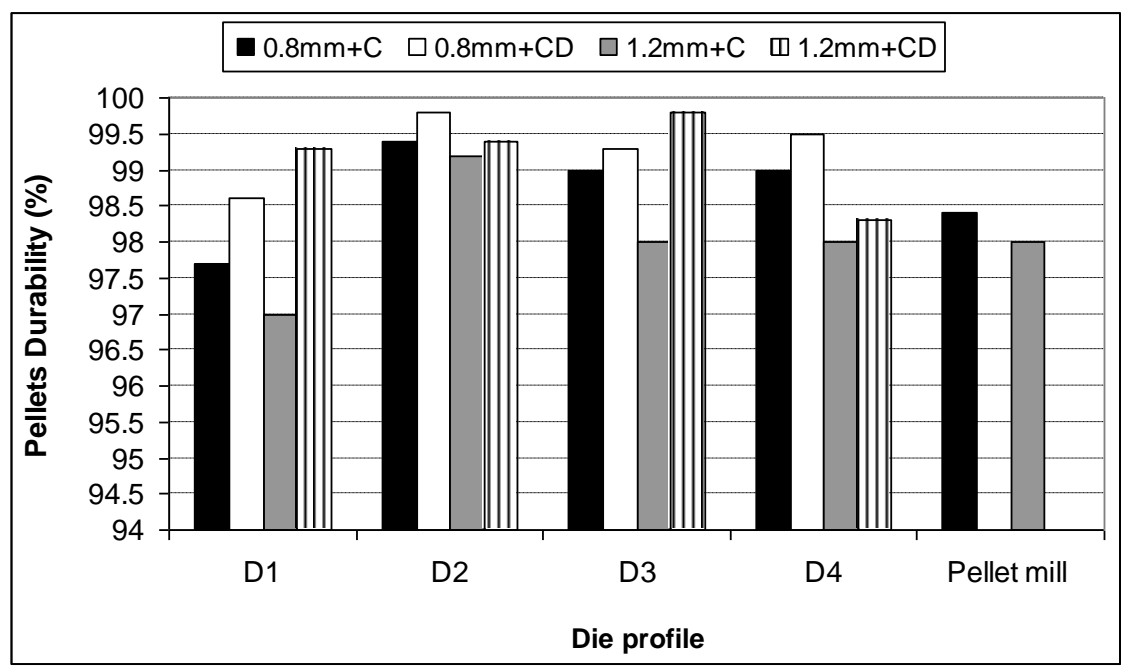

Fig(9) Effect of die holes profile, formula particle size and cooling and drying on pellets durability

The increase in pellets durability by changing the die profile from die 1 to die 2 and from die 1 to die 3 could be due to the increase in die hole land length and increased the formula retention time in the die hole, and the decrease in die opening area that increased the SME inside the extruder barrel respectively. While the decrease in pellets durability by using the same formula with ring die pelleting machine could be due to the change of pelleting system from extruder to die and rollers system .

Regarding to the effect of formula particle size on pellets durability data in the same figure showed that increase formula particle size from $0.8 \mathrm{~mm}$ to $1.2 \mathrm{~mm}$ decreased the pellets durability from $97.7,99.4,99,99$ and $98.4 \%$ to $97,99.2,98,98$ and $98 \%$ using drying and cooling profile and die profile of 1,2,3,4 and ring die pelleting machine respectively.

The decrease in pellets durability by increasing the formula particle size could be due to the increase in the area between the pellets granules, that breakage the pellets in durability box.

The effect of drying cooling profile data in the same figure showed that changing drying cooling profile from just cooling to drying and cooling increased the pellets durability from $97.7,99.4,99$, and $99 \%$ to 98.6 , 99.8, 99.3 and $99.5 \%$ using formula particle size of $0.8 \mathrm{~mm}$ and from 97 , 
99.2, 98 , and $98 \%$ to $99.3,99.4,99.8$ and $98.3 \%$ using formula particle size of $1.2 \mathrm{~mm}$, and die profile of $1,2,3$,and 4 respectively.

The increase in pellets durability by using drying and cooling profile could be due to the drying remove the moisture film around the pellets granules, that decreased the breakage pellets and mash in durability box .

\section{Pellets expansion ratio :}

The effect of die profile, formula particle size and drying cooling profile on pellets expansion ratio OE (after extruder) and OD (after drying and cooling ) data in $\operatorname{Fig}(10 \mathrm{~A})$ showed that change the die profile from die 1 to die 2 and from die 3 to die 4 decreased the expansion ratio from 1.29and 1.11 to 1.25 and 1.05 and from 1.98 and 1.79 to 1.54 and 1.41 using formula particle size of $0.8 \mathrm{~mm}$ and from 1.26and 1.14 to 1.25 and 1.01 and from 2.01 and 1.72 to 1.54 and 1.43 using formula particle size of $1.2 \mathrm{~mm}$, while using the same formula with ring die pelleting machine the expansion ratio were 1.07 and 1.06 using particle size of $0.8 \mathrm{~mm}$ and 1.1 and 1.06 using particle size of $1.2 \mathrm{~mm}$ using just cooling $\mathrm{OD}$ and $\mathrm{OE}$ , respectively.

The decrease in pellets expansion ratio by changed the die profile from die 1 to die 2 or from die 3 to die 4 could be due to the increase in die holes land length that decrease the pellets density by decrease the pellets volume.

Data in Fig(10 B) showed that change the die profile from die 1 to die 3 and from die 2 to die 4 increased the expansion ratio from 1.33and 1.11 to 2.03 and 1.63 and from 1.23 and 1.02 to 1.64 and 1.38 using formula particle size of $0.8 \mathrm{~mm}$ and from 1.36and 1.09 to 1.94 and 1.73 and from 1.22 and 1.03 to 1.39 and 1.35 using formula particle size of $1.2 \mathrm{~mm}$, using drying and cooling profile ,and OD and OE , respectively.

The increase in pellets expansion ratio by changing the die profile from die 1 to die 3 or from die 2 to die 4 could be due to the decreased in die out put opening area (number of holes ) that increased the SME inside the extruder barrel, that increased the formula temperature in the die zone and increased the starch gelatinization ratio. 

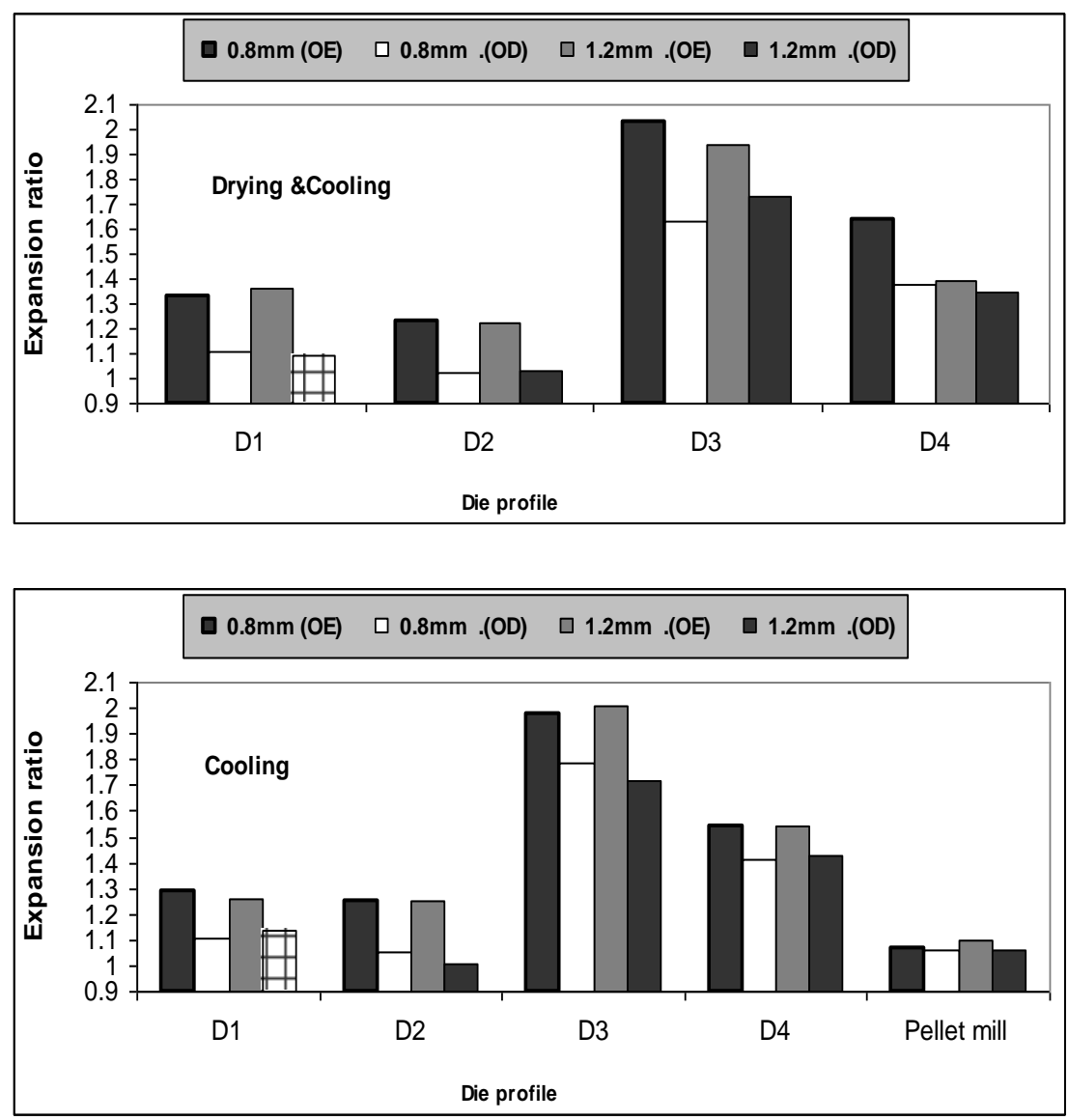

Fig (10A\&B) Effect of die holes profile, formula particle size after extruded $\mathrm{OE}$ and after cooling $\mathrm{OD}$ on pellet expansion ratio.

\section{Pellets water stability:}

The effect of die profile, formula particle size and cooling profile on pellets water stability percentage, data in Fig (11A\&B) showed that using die profile $1(2.5 \mathrm{~mm}$ land length $\& 6.87 \%$ die opening area $)$ the pellets water stability starting $100 \%$ decreased to $90,80,70$ and $60 \%$ after 1, 3, 12 and 24 hours and from $100 \%$ to 80, 70, 60, 50 and $40 \%$ after 1, 3,6,12 and 24 hours using formula particle size of 0.8 and $1.2 \mathrm{~mm}$ , respectively. While die 2 (5mm land length $\& 6.87 \%$ die opening area ) starting $100 \%$ for 12 hours decreased to $90 \%$ after 24 hours, and from $100 \%$ decreased to $90 \%$ for 12 hours and to $80 \%$ after 24 hours, using formula particle size of 0.8 and $1.2 \mathrm{~mm}$, respectively. Regarding to die 3 
(2.5mm land length $\& 4.54 \%$ die opening area ) the pellets stability starting $100 \%$ decreased to 90 and $80 \%$ after 3 and 24 hours and starting by $100 \%$ decreased to $90,80,70,60,50$ and $30 \%$ after 45 minutes , 1, 3, 6, 12 and 24 hours, using formula particle size of 0.8 and $1.2 \mathrm{~mm}$, respectively. While die 4 (5mm land length $\& 6.87 \%$ die opening area ) starting by $100 \%$ and still for 24 hours, and starting by $100 \%$ and decreased to 80 and $60 \%$ after 12 and 24 hours using formula particle size of 0.8 and $1.2 \mathrm{~mm}$, respectively. Data in same figure showed that the pellets water stability by using the ring die pelleting machine, the pellets water stability started by $100 \%$ and decreased to $60,50,10$ and $0.0 \%$ after 15, 30, 45minutes and 1 hour, and from $100 \%$ to 40,10 and $0.0 \%$ after 15, 30 and 45 minutes. using formula particle size of 0.8 and $1.2 \mathrm{~mm}$ , respectively.

Data in Fig(12A\&B) showed the effect of die profile, formula particle size and drying and cooling profile on pellets water stability percentage, it indicated that using die profile $1(2.5 \mathrm{~mm}$ land length $\& 6.87 \%$ die opening area ) the pellets water stability starting $100 \%$ decreased to 90 , 80 and $70 \%$ after 6,12 and 24hours, and from $100 \%$ to 80,70 , and $60 \%$ after 1, 3 and 24 hours, using formula particle size of 0.8 and $1.2 \mathrm{~mm}$, respectively. While die 2 (5mm land length $\& 6.87 \%$ die opening area ) starting $100 \%$ for 24 hours, and from $100 \%$ to 90 ,and $80 \%$ after 1, and 24 hours using formula particle size of 0.8 and $1.2 \mathrm{~mm}$, respectively. Regarding to die $3(2.5 \mathrm{~mm}$ land length $\& 4.54 \%$ die opening area $)$ the pellets stability starting $100 \%$ decreased to 90 and $80 \%$ after 12 and 24 hours and from $100 \%$ to 90,70 and $50 \%$ after land 24 hours using formula particle size of 0.8 and $1.2 \mathrm{~mm}$, respectively. While die $4(5 \mathrm{~mm}$ land length $\& 6.87 \%$ die opening area ) starting by $100 \%$ and decreased to $90 \%$ after 24 hours, and from $100 \%$ to $90,80,70,60$ and $50 \%$ after 15minutes, 1, 6, 12 and 24 hours , using formula particle size of 0.8 and $1.2 \mathrm{~mm}$, respectively

Data in same figure showed that the pellets water stability by using the ring die pelleting machine, the pellets water stability started by $100 \%$ and decreased to $60,50,10$ and $0.0 \%$ after 15,30, 45minutes and 1 hour , and from $100 \%$ to 40,10 and $0.0 \%$ after 15,30 and 45 minutes. using formula particle size of 0.8 and $1.2 \mathrm{~mm}$, respectively. 

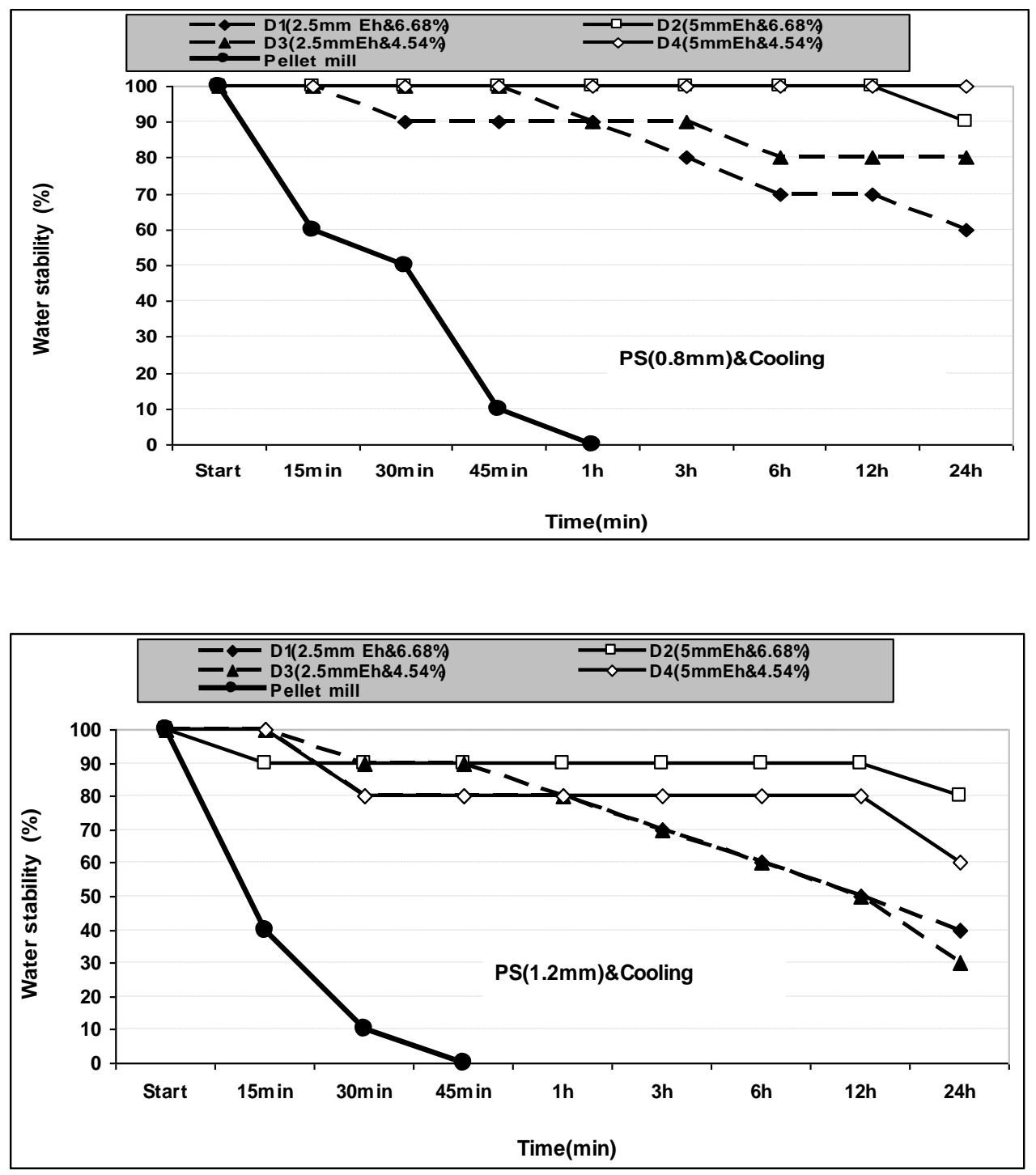

Fig (11 A\&B) Effect of die holes profile on pellet water stability A: using formula particle size of $0.8 \mathrm{~mm}$ and cooling B: using formula particle size of $1.2 \mathrm{~mm}$ and cooling profile 

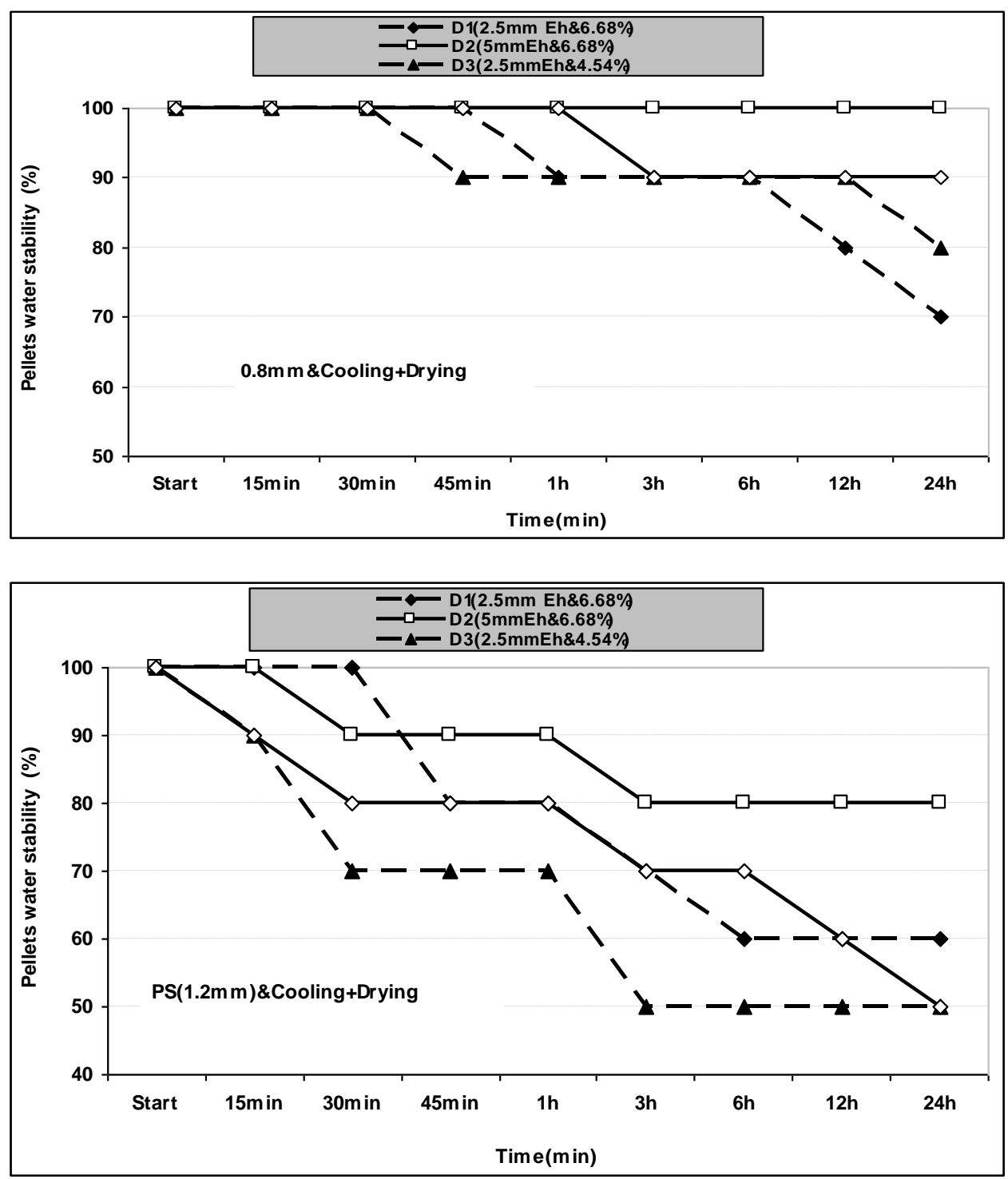

Fig (12A\&B) Effect of die holes profile on pellet water stability A: using formula particle size of $0.8 \mathrm{~mm}$ and cooling $B$ : using formula particle size of $1.2 \mathrm{~mm}$ and drying \&cooling profile

From the data it is clear to see that, the pellets produced by die profile 2 and die profile 4 are more stable in water than that produced by die 1 or 3 that could be due to the decreased in die out put area and the increase in 
SME inside the extruder barrel with increase in starch gelatinization ratio, the gelatin make walls around the air cells makes the water can not go through this walls to broken the pellets into small parts the results showed that the increase in pellets bulk density not meaning the increase in pellets water stability, but the increase in SME and cooking inside the extruder meaning increase in pellets water stability.

\section{Pellets sinking percentage :}

The effect of die profile, formula particle size and cooling profile on pellets sinking percentage, data in Fig (13A\&B) showed that using die profile 1 ( $2.5 \mathrm{~mm}$ land length $\& 6.87 \%$ die opening area ) the sinking percentage starting $100 \%$ for 6 hours and decreased to $90 \%$ after 12 hours and back to $100 \%$ after 24 hours using formula particle size of $0.8 \mathrm{~mm}$, and start by $90 \%$ for 24 hours using formula particle size of $1.2 \mathrm{~mm}$, while die 2 (5mm land length $\& 6.87 \%$ die opening area ) starting $100 \%$ for 30 minutes and decreased to $90 \%$ for 1 hours , $50 \%$ after 12 hours and increased again to $80 \%$ after 24 hours using formula particle size of $0.8 \mathrm{~mm}$, and starting $100 \%$ for 45 minutes and decreased to $50 \%$ for 6 hours , 30\% after 12 hours and increased again to $90 \%$ after 24 hours using formula particle size of $1.2 \mathrm{~mm}$.,regarding to die $3(2.5 \mathrm{~mm}$ land length $\& 4.54 \%$ die opening area )the sinking percentage starting by $100 \%$ for 24 hours using particle size of $0.8 \mathrm{~mm}$ and $1.2 \mathrm{~mm}$., while die 4 (5mm land length $\& 6.87 \%$ die opening area ) the sinking percentage starting $0.00 \%$ and changed to $10,20,40,30,10$ and $50 \%$ after 15 , 45miutes , 3, 6, 12 and 24 hours ,respectively, using formula particle size of $0.8 \mathrm{~mm}$ and starting from $70 \%$ for 24 hours using $1.2 \mathrm{~mm}$ particle size .regarding to the sinking percentage using the ring die pelleting machine , it starting by $100 \%$ for 45 minutes and decreased for $0.00 \%$ after 1 hour using formula particle size of $0.8 \mathrm{~mm}$ and $1.2 \mathrm{~mm}$.with just cooling profile .

Data in Fig (14A\&B) showed that using die profile $1(2.5 \mathrm{~mm}$ land length $\& 6.87 \%$ die opening area ) the sinking percentage starting by $50 \%$ changed to $70,80,50,60$ and $100 \%$ after 15,30 minute , 6, 12 and 24 hours, using formula particle size of $0.8 \mathrm{~mm}$, and starting by $30 \%$ changed to $70,60,50,60,40$ and $100 \%$ after 15,30 minutes ,3, 12 and 24 hours 
using formula particle size of $1.2 \mathrm{~mm}$, while die 2 (5mm land length $\& 6.87 \%$ die opening area ) starting by $60 \%$ changed to $90,80,70$ and $100 \%$ after 15 minute , 6,12, and 24 hours using particle size of $0.8 \mathrm{~mm}$ and starting by $60 \%$ changed to 100 after 45 minute, $90 \%$ after 6 hours and to $100 \%$ after 24 hours using particle size of $1.2 \mathrm{~mm}$, regarding to die $3(2.5 \mathrm{~mm}$ land length $\& 4.54 \%$ die opening area $)$ the sinking percentage starting by $40 \%$ changed to $70 \%$ after 45 minutes , $100 \%$ after 1 hour $70 \%$ after 12 hour and $100 \%$ after 24 hours using $0.8 \mathrm{~mm}$ particle size and starting by $70 \%$ changed to 90,80 , and $100 \%$ after 15,30 minute, 12 and 24 hours using particle size of $1.2 \mathrm{~mm}$ while die $4(5 \mathrm{~mm}$ land length $\& 6.87 \%$ die opening area ) the sinking percentage starting $40 \%$ changed to 50, 40, 50 and $80 \%$ after 30minutes ,6, 12 and 24 hours using formula particle size of $0.8 \mathrm{~mm}$, and starting $100 \%$ for 24 hours using particle size of $1.2 \mathrm{~mm}$. using drying and cooling profile. The change in pellets sinking percentage by time could be due to the change of the pellets water stability

The obtained data showed the effect of die profile(die hole land length and die opening area), formula particle size and drying and cooling profile on extruder efficiency measurements ( extruder productivity and specific mechanical energy SME) and on pellets quality measurements ( pellets out put moisture content, pellets bulk density, pellets durability, pellets expansion ratio, pellets water stability and pellets sinking percentage) .

The effect of die profile, it is clear to see that increasing the die hole land length from 2.5 to $5 \mathrm{~mm}$, decreased the extruder productivity ,increased the SME, deceased the pellets out put moisture content OE(after extruder),increased the pellets bulk density, increased the pellets durability, decreased the pellets expansion ratio, increased the pellets water stability and decreased the pellets sinking percentage that could be due to the increase in formula retention time in the die hole, while decreased the die holes opening area from $6.68 \%$ to $4.54 \%$ decreased the extruder productivity, increased the SME, deceased the pellets out put moisture content $\mathrm{OE}$ (after extruder),decreased the pellets bulk density, increased the pellets durability, increased the pellets 
expansion ratio, increased the pellets water stability and increased the pellets sinking percentage, that could be due to the increase of formula retention time, SME inside the extruder barrel and the high increase in formula temperature.
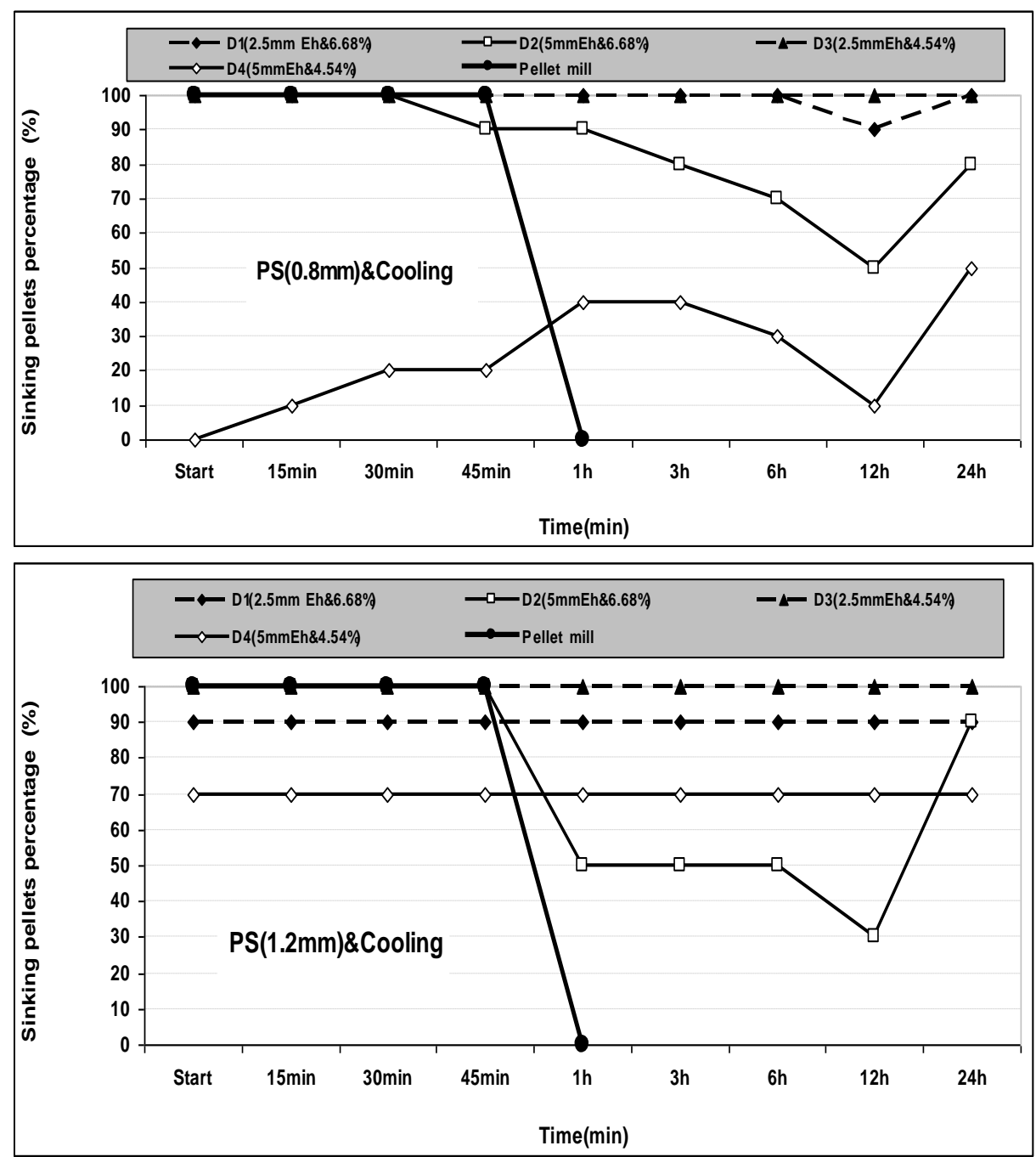

Fig (13) Effect of die holes profile on pellet sinking percentage A:

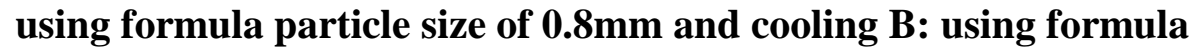
particle size of $1.2 \mathrm{~mm}$ and cooling profile 

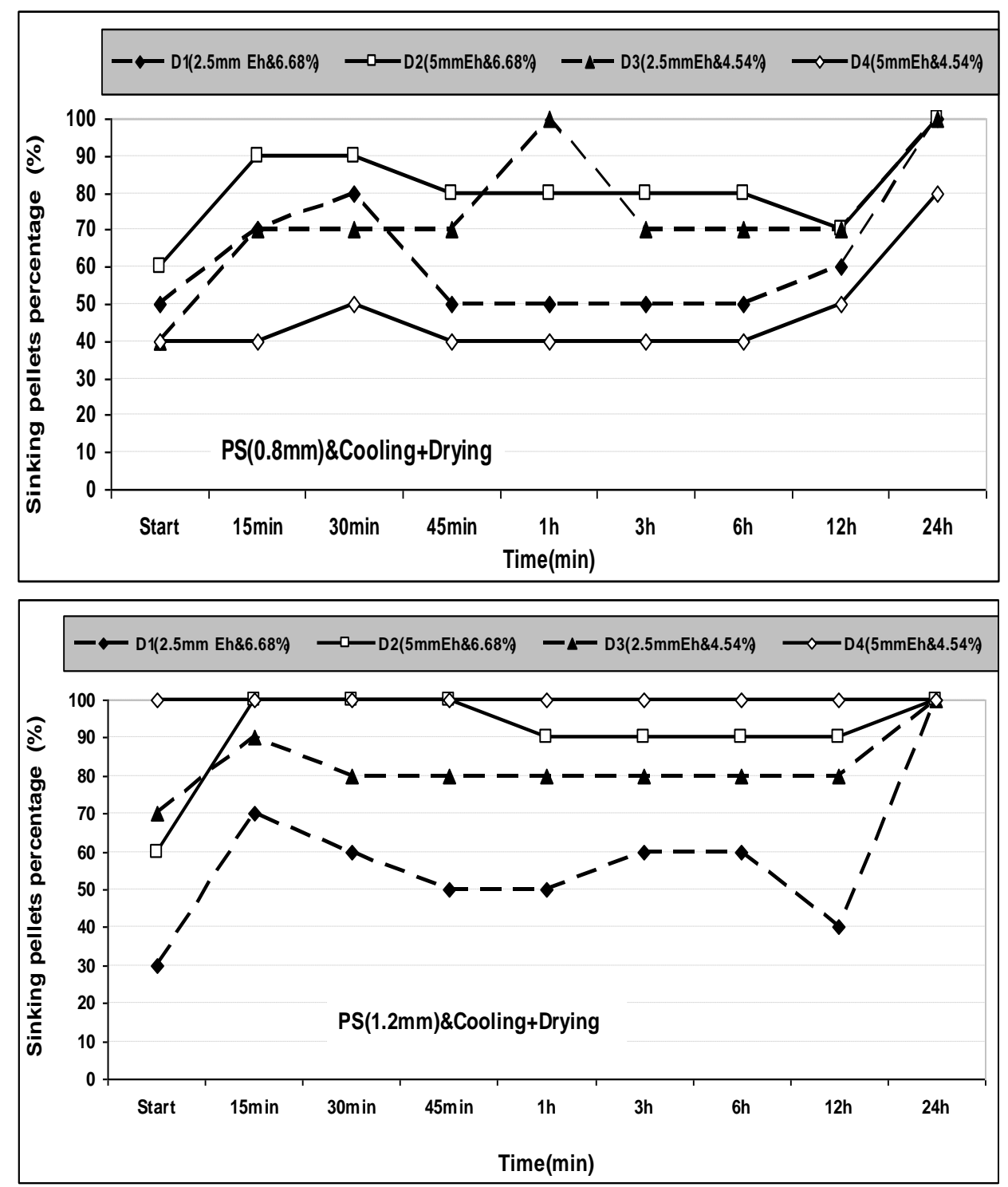

Fig (14) Effect of die holes profile on pellet sinking percentage A: using formula particle size of $\mathbf{0 . 8 \mathrm { mm }}$ and cooling $\mathrm{B}$ : using formula particle size of $1.2 \mathrm{~mm}$ and drying \& cooling profile

The effect of formula particle size, data showed that increased the formula particle size from 0.8 to $1.2 \mathrm{~mm}$ no effect on extruder productivity, no effect on the SME, deceased the pellets out put moisture 
content OE(after extruder),decreased the pellets bulk density, decreased the pellets durability, no effect trend on the pellets expansion ratio, decreased the pellets water stability and no trend effect on the pellets sinking percentage.

The effect of drying and cooling profile ,data showed that using drying and cooling profile not affecting the extruder productivity and extruder SME, but it decreased the pellets deceased OD(after drying and cooling ),decreased the pellets bulk density, increased the pellets durability, decreased the pellets expansion ratio, increased the pellets water stability and increased the pellets sinking percentage.

\section{CONCLUSION}

Aquatic feed production is an important application of extrusion processing. This study focused on the effect of formulation particle size and processing parameters on physical and stability characteristics of extruded sinking shrimp feed. The parameters studied were ration particle size $(0.8 \mathrm{~mm}$ and $1.2 \mathrm{~mm})$, single screw extrusion die profile (land length of 2.5 and $5.0 \mathrm{~mm}$; die output area percentage of 4.5 and $6.7 \%$ ), and drying conditions (cooling only and drying followed by cooling). The single screw extruder die L/D ratio was 30: 1 , with outlet diameter of $2.5 \mathrm{~mm}$. The same formulation was also pelleted by a ring die pellet mill with die L/D ratio of 13.3: 1 and diameter of $2.38 \mathrm{~mm}$, followed by only cooling of pellets. The quality of feed obtained by extrusion and pellet mill were evaluated. The optimum parameters for sinking feed production by extrusion were - formulation particle size of $0.8 \mathrm{~mm}$, die profile with $5.0 \mathrm{~mm}$ land length and $6.7 \%$ die output area percentage, and drying for $10.5 \mathrm{~min}$ at $210 \mathrm{oC}$ followed by cooling for 5.5 min. It is recommended that, for shrimp or sinking aqua feed pellets the extrusion system obtained the high quality of pellets for more pellets water stability than using ring die system .

\section{REFERENCES}

BRIAN P.; P.E. STRAHM AND K.RAUSCH 2001. The Phase Transition Analyzer ${ }^{\mathrm{TM}}$ and its Impact on Extrusion Processing of Foodstuffs. 2001 ASAE Annual International MeetingSponsored by 
ASAE Sacramento Convention Center Sacramento, California, USA July 30-August 1, 2001.

CHINNASWAMY.R., AND HANNA,M.A. 1987. Nozzle dimension effects on the expansion of extrusion cooked corn starch. Journal of food science. 52(6):1746-1747

DVID, A. F.2003. Pelleting for Profit - Part 1. National Grain and Feed Association Volume 54, Number 6, November 13, 2003.

GILPIN A.S. T. J. HERRMAN, K. C. BEHNKE, AND F. J. FAIRCHILD 2002. Feed moisture, retention time, and steam as quality and energy utilization determinants in the pelleting process. 2002 American Society of Agricultural Engineers Vol. 18(3): 331338.

HILL, B. AND D.A. PULKINEN. 1988. A study of factors affecting pellet durability and pelleing efficiency in the production of dehydrated alfalfa pellets. A special report, Saskatchewan Dehydrators Association, Tisdale, SK, Canada: 25.

JAMES H.TIDWELL, CARL D WEBSTER, DANIEL H YANCEY AND LOUIS R D'ABRAMO. 1993. Partial and total replacement of fish meal with soybean meal and distillers' by-products in diets for pond culture of the fresh water prawn (Macrobrachium rosenbergii). Aquaculture, 118:119-130.

KIM,C.N., JOSEPH,A.M., AND JEFFERY,T.M. 1989. Properties of Extruded dried distillers grains (DDG) and flour blends. Journal of Food processing and preservation, 13: 219-231.

LARSEN, T.B., S. SOKHANSANJ, R.T. PATIL AND W.J. CRERAR. 1996. Breakage susceptibility studies on alfalfa and animal feed pellets. Canadian Agricultural Engineering 38(1): 2124.

MERCIER,C.,P.LINKO, AND J.M.HARPER. 1989. Extrusion cooking. American Association of Cereal Chemists, Inc. St. Paul, Minnesota,USA.

NEHRU C.; K.A. ROSENTRATER AND K. MUTHUKUMARAPPAN. 2005. Utilization of Distillers ried 
Grains for Fish Feed by Extrusion Technology - A Review 2005 ASAE Annual International Meeting Sponsored by ASAE Tampa Convention Center Tampa, Florida 17 - 20 July 2005.

\section{NEHRU C; K.A. ROSENTRATER AND K. MUTHUKUMARAPPAN.} 2005. Physical Properties of Extruded Tilapia Feed with Distiller Dried Grains with Solubles 2005 ASAE Annual International Meeting Sponsored by ASAE Tampa Convention Center Tampa, Florida 17 - 20 July 2005 .

TABIL, L.G. AND S. SOKHANSANJ. 1996. Process conditions affecting the physical quality of alfalfa pellets. American Society of Agricultural Engineers 12(3): 345-350.

\section{VICTOR Y.W, RONALD R, ROSTAGI, DAVID J, SESSA AND} PAUL B.BROWN.1994. Utilization of protein rich Ethanol Coproducts from Corn in Tilapia Feed. JAOCS 71(9):1041 - 1043.

\section{الملخص العربي}

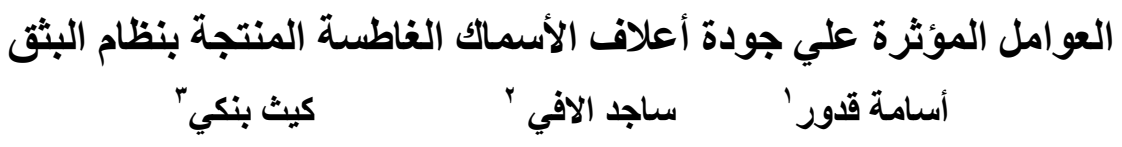

أجري البحث في معمل آلات البثق بجامعة كانساس الأمريكية بهدف دراسة العوامل الفيزيقية

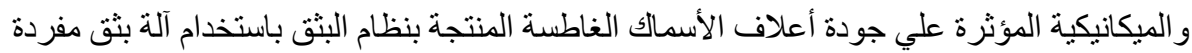

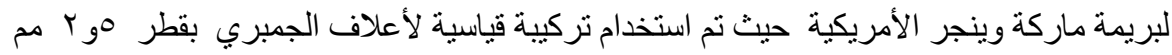

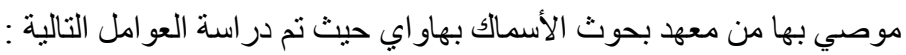

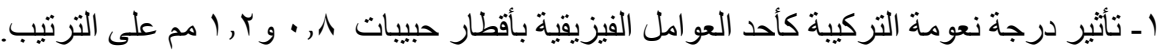

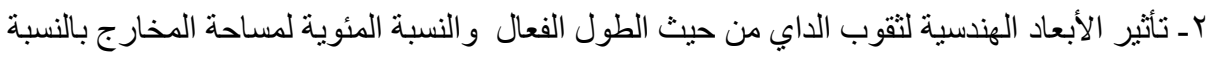

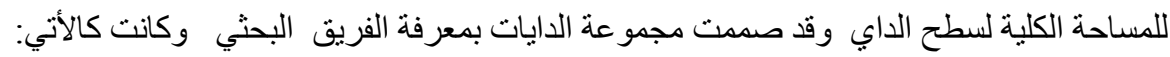

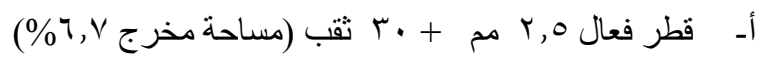

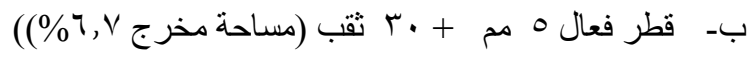

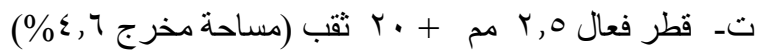

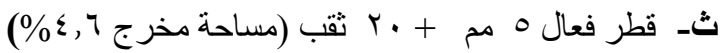

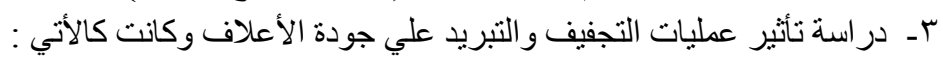

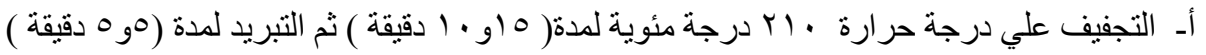

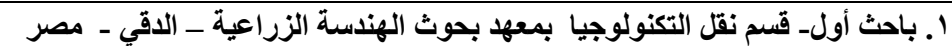

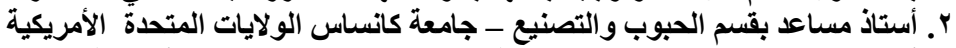

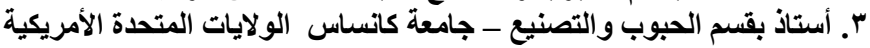


ب- التبريد فقط لمدة (0و 0) دقيقة

و تم استخدام نفس التركيبة الإنتاج أعلاف الجمبري باستخدام آلة كبس حلقية ماركة كاليفورنيا بليت ميل

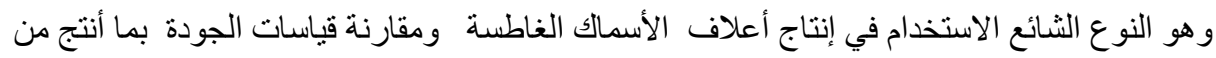
الة البثق للوقوف علي أهمية عمليات الطبخ وتأثثر ها علي ثبات الأعلاف في الماء وقد أثنارت النتائج

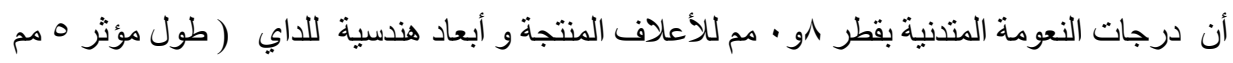

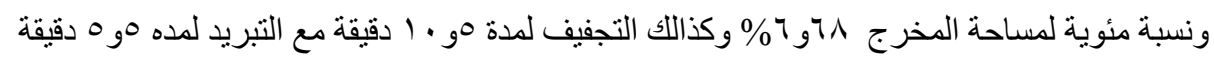
أعطت نتائج أفضل لأداء الآلة وجودة الأعلاف المنتجة وكأو وكانت كالأتي :

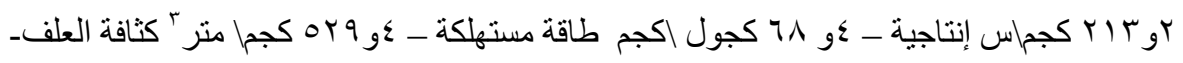

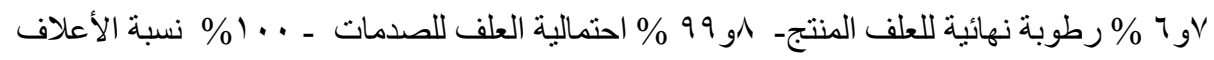

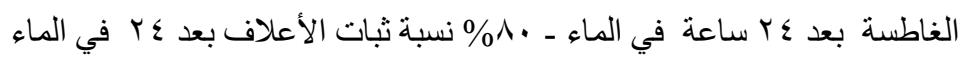

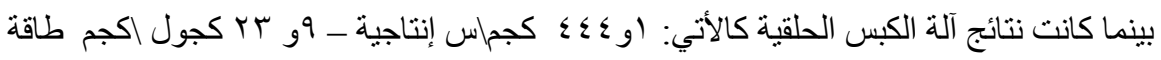

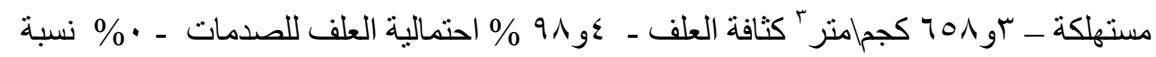

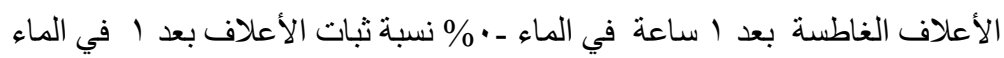

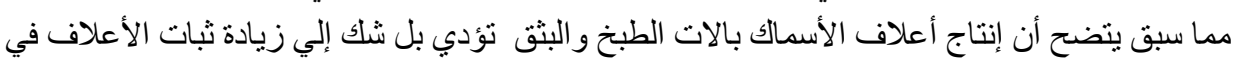

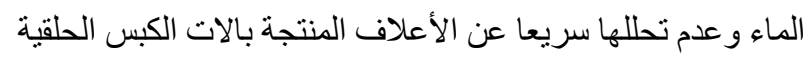

